\title{
Niacin in Puerto Rican Coffees ${ }^{1}$
}

\author{
Conrado F. Asenjo, Angela Cristina A. Draz-Rivera, and Eva Recio ${ }^{2}$
}

\section{INTRODUCTION}

In 1945, Teply, Krehl, and Elvehjem $(1)^{3}$ found roasted coffee to contain considerably more nicotinic acid than green coffee. They suspected that during the roasting operation, trigonelline, the $\mathrm{N}$-methyl-betaine of nicotinic acid, and perhaps other compounds, were transformed into niacin. Other investigators have confirmed these observations $(2,3,4,5)$.

The objective of this paper is to report the results of a study undertaken to determine the niacin content of different varieties of Puerto Rican coffee beans while green and when roasted, of coffee concentrates locally consumed, and of the coffee beverage as prepared and served in Puerto Rico.

\section{MATERIALS AND METHODS}

The samples of coffee investigated were obtained from local sources. The green samples were roasted in a small "Mallorquina" roaster. The temperature used was in the neighborhood of $129^{\circ} \mathrm{C}$., and the roasting time varied from a minimum of 15 to a maximum of 65 minutes. As the charge taken by the Mallorquina roaster is small, only about 2 pounds, the beans were always in intimate contact with the hot surface of the roaster, thus stimulating a rapid and thorough roasting, even though the temperature was not very high.

Six different samples of soluble concentrates or "instant coffee", widely consumed locally, were also assayed.

The samples of coffee beverage assayed for niacin were obtained at random in various places. Some had been prepared by dripping using a flannel colander and others by percolation. Several samples were prepared in the laboratory under standard conditions described later herein.

Niacin was determined microbiologically with Lactobacillus plantarum (Lactobacillus arabinosus 17-5) as test organism. Difco's dehydrated niacin medium was used, although the sample was prepared following the procedure of the Official Methods of the AOAC (6).

${ }^{1}$ A cooperative project between the School of Medicine and the Agricultural Experiment Station, University of Puerto Rico, and the Department of Agriculture of the Commonwealth of Puerto Rico.

2 Professor and Head, Department of Biochemistry and Nutrition, School of Medicine, University of Puerto Rico; Scientific Staff, Department of Agriculture, Commonwealth of Puerto Rico; and Research Assistant, School of Medicine, University of Puerto Rico, San Juan, P.R., respectively.

3 Italic numbers in parentheses refer to Literature Cited, pp. 191-2. 
Moisture was determined by heating the samples to $100^{\circ} \mathrm{C}$. in an oven to constant weight.

\section{RESULTS AND DISCUSSION}

\section{NIACIN CONTENT OF DIFFERENT BRANDS OF LOCALLY ROASTED COFFEES}

Six samples of commercially roasted coffee obtained in stores in the Metropolitan Area of San Juan, had an average moisture content of 5.4 with a range from 4.5 to 6.2 , and an average niacin content of $21.3 \mathrm{mg}$. per 100 gm., with a range from 16.7 to $26.8 \mathrm{mg}$. per $100 \mathrm{gm}$. (table 1).

The roasting temperatures used in large-scale roasting operations in Puerto Rico range from $210^{\circ}$ to $235^{\circ} \mathrm{C}$., applied for periods of 20 to 25 minutes. The average niacin contents of these retailed brands of roasted

TABLE 1.-Niacin in roasted coffees retailed in San Juan, P.R.

\begin{tabular}{|c|c|c|}
\hline Locally roasted coffec brands & Moisture & Niacin per $100 \mathrm{gm}$. as sold \\
\hline & Percent & Mfillgrams \\
\hline A & 4.5 & 24.7 \\
\hline B & 6.2 & 20.5 \\
\hline C & 5.3 & 16.7 \\
\hline $\mathbf{D}$ & 5.1 & 21.8 \\
\hline E (sample 1) & 5.1 & 17.4 \\
\hline E (sample 2) & 6.0 & 26.8 \\
\hline Average & 5.4 & 21.3 \\
\hline
\end{tabular}

coffees compare favorably with those reported in the literature for coffees from other areas where a high roast is used $(4,5)$. In Continental United States coffee is roasted less intensely than in Puerto Rico and many Latin American communities, and this produces a roasted bean of lighter color and lower niacin content (7).

According to Hughes and Smith (2) the nicotinic acid content of raw coffee is not dependent on variety, although Bressani and Navarrete (5) have some evidence to the contrary. The content of trigonelline could depend upon variety, altitude, or the method used in processing the bean (5). As trigonelline is the principal substance transformed by the action of heat into niacin, the quantity present in the green bean could determine the niacin content of the final roasted product $(3,5,7)$. Adamo $(8)$ has determined trigonelline in Puerto Rican green coffee beans and found them to contain from 1.22 to 1.28 percent. These values are not significantly different from those found by this same investigator in coffee beans from other countries. He also determined niacin in roasted samples of Puerto 
Rican coffee, probably obtained in Italy, and reported values ranging from 45 to $51 \mathrm{mg}$. per $100 \mathrm{gm}$. These values are higher than those recorded by us.

\section{EFFECT OF ROASTING TIME ON NIACIN CONTENT OF DIFFERENT VARIETIES AND SELECTIONS OF LOCAL COFFFE BEANS}

Two different varieties of local coffee beans, and the selection known as "Caracolillo", were roasted at an average temperature of $129^{\circ} \mathrm{C}$., for dif-

TABLE 2.-Effect of roasting time on niacin content of local varieties and selections of coffee (green bean) 1

\begin{tabular}{l|c|c|c}
\hline \multicolumn{1}{c|}{ Coffee type } & Roasting time & Moisture & $\begin{array}{c}\text { Niacin per } 100 \mathrm{gm} . \text { of } \\
\text { roasted coffec }\end{array}$ \\
\cline { 2 - 4 } Bourbon variety & Jfinules & Percent & Milligrams \\
& 0 & 8.6 & 1.1 \\
& 35 & 2.8 & 5.4 \\
45 & 1.9 & 10.3 \\
Caracolillo selection & 55 & 1.6 & 14.6 \\
& 65 & 2.0 & 17.0 \\
& 0 & 8.6 & 1.0 \\
& 15 & 2.3 & 7.9 \\
Puerto Rico variety & 30 & 1.9 & 11.2 \\
& 45 & 1.7 & 34.4 \\
& 0 & 9.4 & .9 \\
& 30 & 2.9 & 9.2 \\
& 45 & 2.1 & 11.9 \\
& 55 & 2.0 & 14.4 \\
& 65 & 2.4 & 13.4 \\
\hline
\end{tabular}

1 The roasting temperature was in the neighborhood of $129^{\circ} \mathrm{C}$.

ferent periods of time, in a Mallorquina roaster. The niacin content of the green coffee beans fluctuated between 0.9 and $1.1 \mathrm{mg}$. per $100 \mathrm{gm}$. fresh. These values are in close agreement with those reported in the literature by other investigators $(3,4,5,7)$.

It was observed that, as the roasting time increased, the niacin increased accordingly, while the moisture content generally decreased, as shown in table 2.

The "Caracolillo" selection had the highest niacin content after 45 min-

"The socalled "Caracolillo" coffee is a coffee bean hand-selected on the basis of its rounded shape. The usual coffee bean is convex-shaped on one side and flat on the other. Any one of the known species and varieties within species of coffee yields $\Omega$ certain percentage of these atypical round-shaped beans $(9)$. 
utes of roasting, $34.4 \mathrm{mg}$. per $100 \mathrm{gm}$., while the Bourbon and the Puerto Rico varieties contained 10.3 and $11.9 \mathrm{mg}$. per $100 \mathrm{gm}$., respectively.

\section{SOLUBLE COFFEE CONCENTRATES}

The niacin content of six samples of soluble coffee concentrates are shown in table 3; they ranged in niacin content between 17.4 and $59.5 \mathrm{mg}$. per 100 gm. The moisture content averaged 7.7 percent. Moisture was rather difficult to determine in these samples as coffee concentrates are highly hygroscopic.

To prepare an average cup of coffee, $200 \mathrm{ml}$., ahout 1 teaspoonful, of concentrate is generally used. It weighs in the neighborhood of $10 \mathrm{gm}$., and a cup of coffee thus prepared supplies from 1.7 to $5.9 \mathrm{mg}$. of niacin, depending on the particular concentrate used.

TABLE 3.-Niacin content of concentrated soluble coffees of different brands in the San Juan market

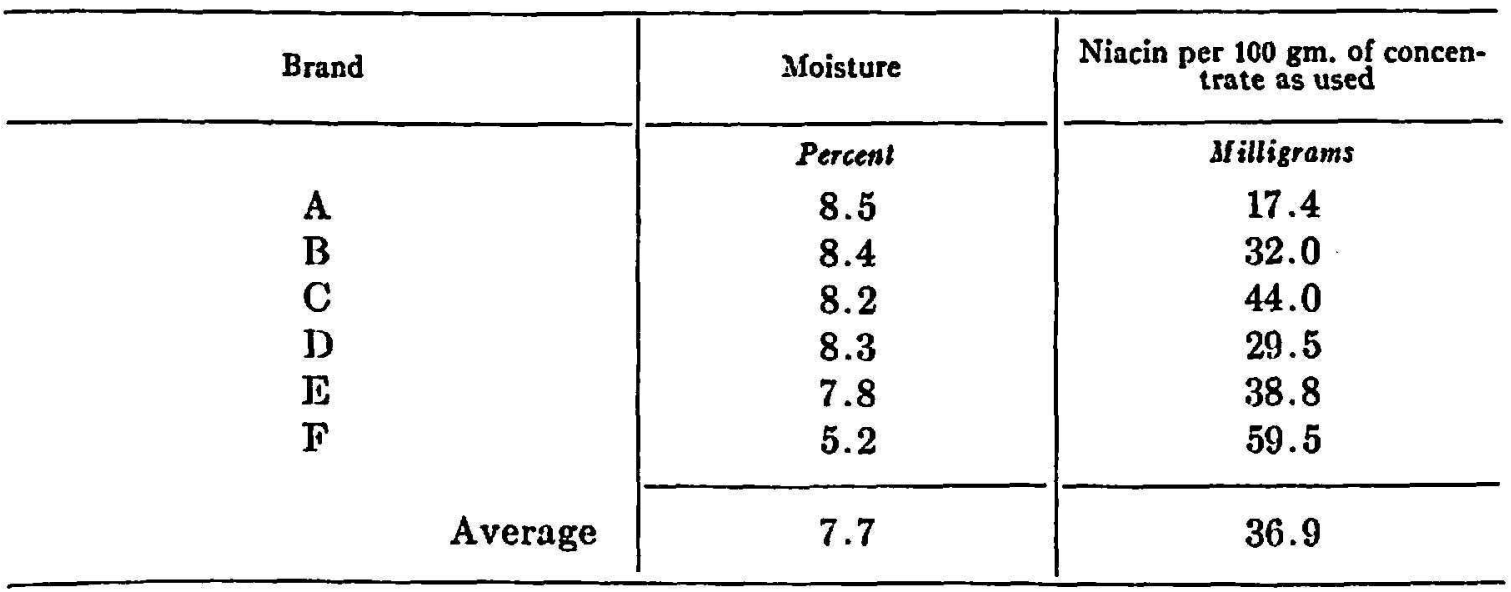

NIACIN CONTENT OF LOCAL COFFEE BEVERAGE

In table 4 is shown the niacin content of the coffee beverage as prepared in San Juan either by dripping, percolation, or boiling. The last-mentioned procedure was utilized in the laboratory, using known quantities of both water and coffee.

Samples of homemade coffee beverage supplied by various members of the laboratory staff averaged $2.0 \mathrm{mg}$. per $100 \mathrm{ml}$. of beverage, with a range from 0.91 to $4.5 \mathrm{mg}$. of niacin per $100 \mathrm{ml}$. This coffee had been prepared in a flannel colander by dripping. Other samples prepared in percolators averaged $1.3 \mathrm{mg}$. per $100 \mathrm{ml}$. of beverage, with a range from 1.1 to $1.6 \mathrm{mg}$. per $100 \mathrm{ml}$. Samples prepared in the laboratory rated higher, $3.5 \mathrm{mg}$. per 100 $\mathrm{ml}$. of beverage, with a range from 3.4 to $3.6 \mathrm{mg}$. per $100 \mathrm{ml}$.

Using the average of all the samples assayed, $2.3 \mathrm{mg}$. per $100 \mathrm{ml}$., and assuming a daily consumption of two cups of coffee with milk, containing 
$50 \mathrm{ml}$. of coffee beverage and $150 \mathrm{ml}$. of milk, the daily intake of niacin supplied by this quantity of coffee is in the neighborhood of $2.3 \mathrm{mg}$. per day, or about 14 percent of the National Research Council-recommended daily allowance for an average adult. It is interesting that the niacin in the Puerto Rican coffee beverage came close to that reported from Mexico (3), about $2.0 \mathrm{mg}$. per $100 \mathrm{ml}$., and Venezuela (4), about $2.6 \mathrm{mg}$. per 100 $\mathrm{ml}$. However, the quantity reported from Guatemala (5) was much lower, $0.59 \mathrm{mg}$. niacin per $100 \mathrm{ml}$.

TABLE 4.-Niacin content of coffee beverage as prepared in Puerlo Rico

\begin{tabular}{|c|c|c|c|}
\hline Sample No. & Source and procedurel & Samples & Niacin per $100 \mathrm{ml}$. of beverage \\
\hline \multirow{4}{*}{1} & & Number & Milligrams \\
\hline & $\begin{array}{l}\text { Obtained in the homes of members of } \\
\text { the laboratory staff, made- }\end{array}$ & & \\
\hline & $\begin{array}{l}\text { By dripping, using a flannel } \\
\text { colander }\end{array}$ & 10 & 2.0 (range $0.91-4.50$ ) \\
\hline & By use of a percolator & 3 & 1.3 (range $1.1-1.6$ ) \\
\hline \multirow[t]{2}{*}{2} & $\begin{array}{l}\text { Prepared in the laboratory : } 35 \mathrm{gm} \text {. of } \\
\text { roasted coffee boiled for about } 5 \\
\text { minutes with } 350 \mathrm{ml} \text {. of water and } \\
\text { then filtered through a flannel } \\
\text { colander }\end{array}$ & 3 & 3.5 (range $3.4-3.6$ ) \\
\hline & $\begin{array}{l}\text { Average for all the samples } \\
\text { tested }\end{array}$ & & 2.3 (range $0.91-4.5$ ) \\
\hline
\end{tabular}

1 All the coffees used in preparing these coffee beverages were highly roasted and finely ground.

\section{SUMMARY AND CONCLUSIONS}

Samples of roasted coffees retailed in San Juan, P.R., were found to have an average niacin content of $21.3 \mathrm{mg}$. per $100 \mathrm{gm}$., with a range from 16.7 to $26.8 \mathrm{mg}$. per $100 \mathrm{gm}$., a value which compares favorably with those reported in the literature for roasted coffees from other Latin American communities.

Coffee roasted in the laboratory at an average temperature of $129^{\circ} \mathrm{C}$., increased in niacin content in proportion to the roasting time. The "Caracolillo" selection recorded the highest content of niacin after 45 minutes of roasting, $34.4 \mathrm{mg}$. per $100 \mathrm{gm}$., in comparison to two other local varieties: Bourbon, $10.3 \mathrm{mg}$. per $100 \mathrm{gm}$., and Puerto Rico, $11.9 \mathrm{mg}$. per 100 
gm. The niacin content of the green coffee beans ranged from 0.9 to 1.1 mg. per $100 \mathrm{gm}$.

Soluble-coffee concentrates varied greatly in niacin content, ranging from 17 to $59.5 \mathrm{mg}$. per $100 \mathrm{gm}$.

Coffee beverages as prepared in Puerto Rico contained an average of $2.3 \mathrm{mg}$. of niacin per $100 \mathrm{ml}$. It was roughly estimated that at that rate of consumption, and in the form in which coffee is consumed in Puerto Rico, the beverage supplies about 14 percent of the daily allowance of niacin recommended for a healthy adult by the National Research Council.

\section{RESUMEN Y CONCLUSIONES}

El promedio del contenido de niacina en muestras de café tostado de venta al por menor fue de $21.3 \mathrm{mg}$. por cada $100 \mathrm{gm}$. (fluctuando entre 16.7 y $26.8 \mathrm{mg}$. por cada $100 \mathrm{gm}$.). Este promedio compara favorablemente con los promedios en el café tostado de otros países de la América Latina según se informa en la literatura.

El café que se tostó en el laboratorio a una temperatura promedio de $129^{\circ} \mathrm{C}$. aumentó su contenido de niacina en proporción al tiempo que duró el tostado. La selección "Caracolillo" fue la que registró el mayor contenido de niacina después de tostarse por 45 minutos ( $34.4 \mathrm{mg}$. por cada 100 $\mathrm{gm}$.) en comparación con otras dos variedades locales: Las Bor'b 'n (10.3 mg. por cada $100 \mathrm{gm}$.) y la Puerto Rico (11.9 mg. por cada $100 \mathrm{gm}$.). El contenido de niacina en el café en grano sin tostar fluctuó entre 0.9 y $1.1 \mathrm{mg}$. por cada $100 \mathrm{gm}$.

Los concentrados solubles de café varían grandemente en su contenido de niacina, fluctuando entre 17 y $59.5 \mathrm{mg}$. por cada $100 \mathrm{gm}$.

El café que se bebe en Puerto Rico contiene un promedio de $2.3 \mathrm{mg}$. de niacina por cada $100 \mathrm{ml}$. Se hizo un cálculo aproximado según el cual en la forma y frecuencia con que se consume cl café en Puerto Rico, esta bebida sólo provee alrededor del 14 por ciento de la cuota diaria de niacina que requiere un adulto en buena salud de acuerdo con las recomendaciones del Consejo Nacional de Investigaciones de Estados Unidos.

\section{LITERATURE CITED}

1. Teply, L. J., Krehl, W. A., and Elvelijem, C. A., Studies in the nicotinic acid content of coffee, Arch. Biochem. 6 139-49, 1945.

2. Hughes, E. B., and Smith, R. F., Nicotinic acid content of coffee, J. Soc. Chem. Ind. 65 248-86, 1946.

3. Cravioto, R. O., Guzmán G., J., and Suárez S., M. L., Incremento del contenido de niacina (vitamina antipelagrosa) durante la torrefacción del café y su significado en el aporte de esta vitamina a la dieta, Cienc. (Mex.) 16 24-6, 1955.

4. Gross Daum, M., La niacina en el café y su importancia nutricional en Venezuela, Arch. Venezolanos de Nutr. 6 61-70, 1955. 
5. Bressani, R., and Navarrete, D. A., Niacin content of coffee in Central America, Food Res. 24 344-51, 1959.

6. Official Methods of Analysis of the Association of Official Agricultural Chemists, 8th ed., Washington, D.C., 1955.

7. Teply, L. J., and Prier, R. F., Nutritional evaluation of coffee including niacin bioassay, J. Agr. Food Chem. 6 375-7, 1957.

8. Adamo, G., Il contenuto in acido nicotinico nel cafe, Bol. della Soc. Italiana di Biol. Sper. 31 79-82, 1955.

9. Molero, F. J., Especies v variedades de cafetos, Rev. de Agr. de P.R. 44 15-58, 1957. 